\title{
1968-2008: O Veja "Way of Life"
}

\author{
Maria Ribeiro do Valle*
}

\section{Resumo}

O artigo aborda, segundo a nossa hipótese, o Jornalismo espetacular, marcado pelo entretenimento, utilizado pela revista Veja para noticiar os episódios do movimento estudantil - principal movimento engajado na luta da ditadura - já em 1968. Foram feitos pesquisa bibliográfica e estudo comparativo da abordagem de edições de 1998 e de 2008. Durante as comemorações deste ano ímpar, a nossa conclusão é a de que Veja agrega, cada vez mais, elementos sensacionalistas com o intuito de denegrir a imagem do movimento estudantil, corroborando, assim, com a indústria cultural e a sociedade do espetáculo que visam a produzir uma juventude "democrática", ou seja, que almeja o sucesso econômico por meio do direito de consumir e da manutenção do sistema político vigente.

Palavras chave: Veja. Movimento Estudantil. Sociedade do Espetáculo. Indústria Cultural.

\section{8-2008: The Veja "Way of Life" \\ Abstract}

The present article approaches, according to our hypothesis, the Yellow journalism, characterized by the use of entertainment by Veja magazine in reporting the episodes of the student movement - the main movement engaged in the fight against dictatorship - since 1968. We made bibliographic research and a comparative study about the approach of 1998 and 2008's editions. During the celebrations of this unique year, our conclusion is that Veja relies more and more on sensationalist elements in order to stain the image of the student movement, which corroborates the view of the culture industry and the society of the spectacle, which focus on the production of a "democratic" youth, i.e., a group that

\footnotetext{
* Professora Doutora de Sociologia da Faculdade de Ciências e Letras, Universidade Estadual Paulista-UNESP, Campus de Araraquara, Araraquara-SP, Brasil. É autora dos livros "1968 - O Diálogo é a Violência: Movimento Estudantil e Ditadura Militar no Brasil” (2ª edição) publicado pela Editora da Unicamp e "A violência revolucionária em Hannah Arendt e Herbert Marcuse" publicado pela Editora da Unesp. Editora da revista Estudos de Sociologia. E-mail: maria. ribeiro@valle.uol.com.br
}

Intercom - RBCC 
aims at economic success through the right to consume and the maintenance of the current political system.

Keywords: Veja. Student movement. Society of the spectacle. Culture industry.

\section{8-2008: La Veja "Way of Life" Resumen}

El artículo en cuestión acercase, según nuestra hipótesis, del periodístico espectacular, marcada por el entretenimiento, empleado por la revista Veja para informar los episodios del movimiento estudiantil - el principal movimiento comprometido con la lucha contra la dictadura - desde 1968. Esta investigación se construye sobre literatura referente al tema y uno estudio comparativo de aproximación de las ediciones de 1998 y 2008. Durante las celebraciones de esta fecha impar, nuestra conclusión es que la Veja añadí, cada vez más, elementos sensacionalistas con el objetivo de empañar la imagen del movimiento estudiantil, de esta manera corroborando con la industria de la cultura y la sociedad del espectáculo que buscan producir una juventud "democrática", o sea, que aspira por el suceso económico a través del derecho de consumir y del mantenimiento del sistema político en vigor.

Palabras clave: Veja. Movimiento estudiantil. Sociedad del espectáculo. Industria de la cultura.

Introdução

7 rabalhar com a cobertura de Veja sobre os quarenta anos de 1968 neste artigo significa manter a memória deste ano

1 viva. Lançada em setembro de 1968, Veja demorou muito para atingir o sucesso editorial que a caracteriza hoje. No seu início como era produzida por jornalistas engajados, oscilou entre o engajamento político e o Jornalismo, de um lado e o entretenimento, de outro (COELHO; VALLE, 2008, p.138). Paulatinamente vai se tornando um sucesso de vendas e ao longo das décadas em que "comemora" 1968 agrega aos seus acontecimentos doses cada vez maiores de sensacionalismo e entretenimento, desconsiderando todo o significado político e o engajamento de uma juventude em nome de uma outra promissora, bem sucedida economicamente e consumidora.

Uma análise crítica do relato da revista Veja se justifica principalmente pelo fato de ela escamotear o movimento estu- 
dantil - principal movimento engajado na luta contra a ditadura -, reduzindo-o apenas ao deboche. E também porque são muitos os leitores que ficarão com esta imagem que Veja quer construir para o seu significativo público. É importante ressaltar que se ao longo das décadas Veja se distancia de seu modelo inicial de revista de informação e de temas políticos migrando para o Jornalismo espetacular, com temas voltados para o entretenimento, parece que a defesa do status quo foi uma constante em suas matérias.

Tendo por base pesquisa bibliográfica e estudo comparativo da abordagem de edições de 1998 e de 2008 da revista Veja sobre o movimento estudantil, propomos aqui a análise das edições comemorativas de 1968 que trazem à tona com suas matérias o escamoteamento de um movimento de protesto tendo em vista um mundo inserido na lógica global do mercado. A causa desta oscilação vai sendo revelada ao longo do artigo pela própria revista que vai explicitando cada vez mais o mundo e a juventude que Veja quer criar e que, para tanto, 1968, já que ainda insiste em vir à tona, deve ser ao menos distorcido. Assim, o objetivo é comparar o relato de Veja no calor da hora e o de 2008, pois há indicativos da preservação da narração dos acontecimentos políticos do movimento estudantil de 1968, apesar de Veja já criminalizar os estudantes, nas demais décadas, quando a revista seleciona, cada vez mais, apenas os fatos que a permitem construir a imagem de um movimento detrator dos costumes, da moral e da justiça social.

Nossa hipótese é a de que com o passar das décadas há a opção de Veja por uma forma de Jornalismo que privilegia o entretenimento em detrimento da versão política dos acontecimentos, passando a banalizar cada vez mais o ano de1968. Contribui, assim, para a neutralização de nosso passado recente, de movimentos políticos engajados e para a "criação de modelos", disseminados em grande medida pelos meios de Comunicação de massa, ou seja, em nosso caso, pelo "Veja way of Life".

\section{Veja, sociedade do espetáculo e indústria cultural}

A revista Veja foi lançada em 11 de setembro de 1968 seguindo o modelo news magazine, importado dos Estados Unidos, 
particularmente da revista Time, no qual predominam os temas de atualidade e de informação geral (cf. Villalta, 2002). No entanto, Carnevalli afirma que as revistas de informação, como no caso de Veja, têm se distanciado de seu modelo inicial (2003, p.11), no sentido de uma migração para temas voltados a entretenimento e utilidades, desviando-se da temática política (Dornelles, s/d, p.6).

A nosso ver a revista se aproxima cada vez mais da lógica da sociedade do espetáculo que, segundo Guy Debord (1997, p.15), interfere na capacidade do homem de ver e interpretar criticamente o mundo, alienando-o da sociedade, perpetuando a lógica de um sistema capitalista que se baseia no acúmulo de bens. Essa lógica vai ser transmitida pelos meios de Comunicação e isso vai reger o comportamento das pessoas, que tenderão a se comportar de acordo com os modelos apresentados pela mídia. A organização moderna dos meios de Comunicação é caracterizada por estratégias que constroem um "novo mundo" pautado no desejo de consumo. Na sociedade do espetáculo há a uniformização exercida pela cultura de massa. Ela trabalha a imagem da sociedade da abundância ${ }^{1}$, pois essa afirmação dá a falsa impressão de que a indústria cultural, tão criticada por Adorno (2009), possui uma face democrática no que diz respeito ao direito de consumir (Porto ; Caixeta, 2009, p.199). Há a perversão da vida moderna que prefere a imagem e a representação ao realismo concreto e natural, a aparência ao ser, a ilusão à realidade, a imobilidade à atividade de pensar e agir com dinamismo.

Veja passa a ser, segundo a nossa leitura, um veículo de espetacularização, uma vez que ela divulga modos de vida e padrões de comportamento principalmente numa época de uniformização da cultura, ou seja, de valores, regras e deveres moldados segundo uma minoria capitalista dominante. Portanto, ela instrumentaliza as relações sociais com o objetivo de estimular o comportamento de consumo e o cultivo da postura de passividade e de isolamento, o que dificulta um entendimento e uma atitude contestatória da sociedade vigente (Debord, 1997, p.20 e 21). A indústria cultural

\footnotetext{
${ }^{1} \mathrm{Na}$ fase de superprodução o sistema capitalista passa a considerar o proletário como consumidor e não apenas como o operário da fase primitiva da acumulação capitalista.
} 
é privilegiada por Veja com a generalização de seu modo de vida e de seus valores enquanto a dimensão crítica e questionadora desta sociedade, isto é, o mundo da contestação, se enfraquece.

Para Marcuse (1982), a Modernidade constituiu-se num momento histórico que inspirou um projeto de dominação da natureza, sustentado no desenvolvimento científico e tecnológico, portanto, de racionalidade tecnológica. Esta etapa da história humana prometeu ao homem autonomia e emancipação, porém, teve como conseqüência o controle e o domínio sobre a humanidade. Esta racionalidade, que está presente em todas as esferas da vida, amplia seus controles ao homem, molda seu comportamento, sua cultura e a sociedade como um todo. Tal domínio comprova que esta racionalidade tecnológica se transformou em racionalidade política, determinando necessidades individuais e coletivas e combatendo, de modo eficiente, qualquer tipo de manifestação de oposição aos sistemas político e econômico que ela inaugurou, desqualificando e isolando suas críticas com o controle generalizado de corações e mentes.

O fechamento do universo da locução, tematizado assim por Marcuse, que também é o fechamento da possibilidade de fazer a crítica à sociedade regida pelos valores da mercadoria, tem suas características e efeitos ideológicos agravados na contemporaneidade devido à emergência do que Guy Debord (1997), como vimos, chamou de sociedade do espetáculo e está presente no Jornalismo de Veja.

\section{O primeiro ano de Veja}

Os dois episódios de maior repercussão nacional do ME após o lançamento de Veja foram o da Rua Maria Antônia e o 30o Congresso da UNE. Em 1968, Veja, como vimos, ainda uma revista predominantemente de informação e textual, exerceu o papel de denegrir e, inclusive, delatar as lideranças políticas do ME e de enfatizar a violência de seus episódios, como naquele que ficou conhecido como A guerra da Maria Antônia que tem início no dia dois de outubro. Apesar de em uma guerra não haver como diferenciar agressores e agredidos, a revista aponta para o ataque

Intercom - RBCC

São Paulo, v.35, n.2, p. 129-147, jul./dez. 2012

133 
dos estudantes da Faculdade de Filosofia da USP ressaltando sempre o comando de José Dirceu. Ao divulgar o laudo da autópsia de José Guimarães, a revista Veja questiona a autoria do crime mostrando-a indeterminada, enfatizando as violências praticadas pelos estudantes durante o trajeto, dizendo que não houve paz e criticando a tentativa de utilização política do assassinato de José Guimarães (VALLE, 2010, p.188).

A revista Veja, ao mostrar a composição dos dois grupos em choque, um deles formado por elementos da direita radical - CCC (Comando de Caça aos Comunistas), FAC (Frente Anticomunista) e MAC (Movimento Anticomunista) - e o outro por elementos esquerdistas - pertencentes à ex-UNE (União Nacional dos Estudantes) (cf. Veja, 09/10/68, p.16) - permite-nos inserir o episódio da Maria Antônia na conjuntura política mais ampla caracterizada por grupos extremistas de esquerda e de direita. Veja tece, então, fortes críticas às consequências atingidas pela briga dos estudantes. Tanto assim que questiona o tempo todo o protesto dos estudantes da Filosofia contra a morte de seu colega, pois segundo o seu registro os próprios estudantes são culpados pela mesma, sob o comando de José Dirceu. Mesmo assim, não deixa de registrar a atuação da direita radical, e, pela indeterminação da autoria do assassinato, deixa no ar, talvez a despeito mesmo de sua vontade, para leitores mais atentos, a possibilidade de o assassinato ter sido praticado pela direita como é confirmado anos depois de 1968. Veja, ao dar um espaço maior à descrição dos episódios semanalmente, trazia grandes matérias sobre o movimento estudantil que, além de reforçar seu projeto político, davam espaço para os diferentes atores de 1968, dentre os quais se destacam as autoridades militares e as lideranças estudantis, permitindo, apesar de sua tomada de posição, a leitura de diferentes versões sobre um mesmo fato.

Já sobre o Congresso de Ibiúna, que tem seu desfecho em 12 de outubro, Veja destaca a ausência de violência da polícia no cerco ao Sítio Murundu. Apesar da prisão dos principais líderes estudantis de todo o país, e por isto mesmo, relata a extensão das manifestações em diversos Estados: Salvador, Recife, Florianópolis, Belém, Maceió, Natal, Fortaleza, Ribeirão Preto, Campinas, Vitória, Belo Horizonte e Brasília voltam a ocorrer passeatas e 
comícios-relâmpagos. Na maioria há choques com a polícia que, utilizando-se de forte esquema repressivo, acaba efetuando novas prisões. Em várias capitais, destacando-se São Paulo, Rio de Janeiro e Belo Horizonte, diversas faculdades entram em greve como protesto contra a repressão ao $30^{\circ}$ Congresso da UNE.

Em 1968, Veja descreve a prisão de Vladimir Palmeira, José Dirceu e Travassos com tom aliviado: "Os três líderes estudantis estavam com prisão decretada, finalmente executada depois de muitas vezes terem enganado a polícia" (Veja, 16/10/68, p.12). Mas, mais uma vez admite a independência do ME de suas lideranças uma vez que com a sua permanência na cadeia, as manifestações estudantis continuam devido às três mortes ocorridas em apenas dois dias no Rio de Janeiro durante manifestações estudantis pela soltura de suas lideranças.

De qualquer forma para a revista Veja estes últimos episódios da Guanabara deveriam de forma exemplar levar os estudantes a uma trégua:

Os estudantes, repelidos das ruas sem que a violência e a intolerância contra eles desencadeadas e que fizeram vítimas inocentes mobilizassem, em seu favor, mais uma vez, as grandes parcelas do apoio popular, dão sinais de trégua e parecem dispostos a se recolher às suas bases (Veja, 30/10/68, p.18).

A publicação da Editora Abril como um produto em sintonia com o projeto de modernização do capitalismo, traz na capa de seu primeiro número, os símbolos do comunismo, a foice e o martelo, com a chamada "O Grande Duelo no Mundo Comunista", abordando o tema da invasão da Tchecoslováquia pelo Pacto de Varsóvia, fato que desagradou Victor Civita². Tanto assim que na edição comemorativa dos 20 anos da revista, ao comentar sobre a capa em questão, afirma que "não gostou, porque poderia parecer que estávamos fazendo propaganda dos comunistas" ("Os 20 anos de Veja", OESP, 10/9/88). Podemos notar que a opção de Veja, em seu início, era, de fato, ser uma revista de informações, com temáticas políticas, embora não possamos deixar também de apontar sua tônica anticomunista. Pelo fato de os estudantes estarem contaminados, a seu ver, pela "foice e o martelo", a revista

${ }^{2}$ A família Civita é dona da Editora Abril.

Intercom - RBCC

São Paulo, v.35, n.2, p. 129-I47, jul./dez. 2012 
posicionava-se claramente contrária aos seus protestos. Durante as narrações no calor da hora pode haver um sensacionalismo com relação à violência atribuída aos estudantes, mas a revista ainda não trata os episódios apenas como entretenimento.

\section{Os 30 anos de 1968 por Veja: a revolução moral da Juventude transviada}

Quando 1968 faz 30 anos, Veja apesar de continuar tematizando ações políticas, já começa a trazer fortes traços de sensacionalismo em sua reportagens, voltando-se para questões de entretenimento. Começa com uma matéria especial no dia seis de maio fato que já denota sua visão eurocêntrica devido ao "Maio francês", uma vez que no Brasil os acontecimentos estudantis, inclusive o assassinato do primeiro estudante pela ditadura ocorre em março de 1968. Sua ênfase é dada à contenção da rebeldia ocorrida no terreno dos costumes trinta anos atrás:

A juventude afronta seus pais, hierarcas de todos os tipos e os cânones morais: os universitários querem que garotas tenham acesso irrestrito aos seus dormitórios, e vice-versa. Numa época pré-Aids, os corpos são liberados para a diversão pelos anticoncepcionais. $\mathrm{O}$ sexo nunca mais foi o mesmo (Veja, 06/05/1998, p.74).

Critica assim a contaminação dos EUA que também se transforma no "reduto" da revolução dos costumes: a comunidade dos hippies - sinônimo do sexo e das drogas; a influência da cantora americana Janis Joplin e do guitarrista Jimi Hendrix, "talentos desperdiçados" pelas mortes provocadas pela overdose; a atuação política de intelectuais como Susan Sontag, Norman mailer e James Baldwin que eram adeptos da desobediência civil. Todos estes fatos estavam desvirtuando a juventude americana:

Os jovens eram, como em todas as guerras, a infantaria desse exército de revolucionários. A diferença, a enorme diferença que faria de 1968 uma época peculiar, é que esses jovens não aceitavam os velhos comandantes (Veja, 06/05/1998, p.80).

A liderança-alvo parisiense de Veja é Daniel Cohn-Bendit, que tinha 23 anos em 1968 e em 1988 com 53, justificava: 
nós queríamos uma democracia direta, melhor do que a real, queríamos mudar a linguagem e o estilo de vida, queríamos uma liberação dos costumes, o entusiasmo da solidariedade, a alegria de superar o egoísmo (Veja, 06/05/1998, p.80).

Criticando tenazmente a falta de imaginação da juventude perdida, Veja aponta para o paradoxo de ser libertária ao mesmo tempo em que enaltecia violentas ditaduras totalitárias, sendo nostálgica tanto

"dos mitos revolucionários da Comuna de Paris de 1871 quanto dos brancaleônicos brigadistas internacionais da Guerra Civil Espanhola de 1936, e fascinados pelos mitos de então - a China, com sua Revolução Cultural, o Vietnã e Cuba, particularmente o herói morto um ano antes na selva boliviana. Ernesto Che Guevara" (Veja, 06/05/1998, p.83).

Com o subtítulo "revolta na periferia" aborda 1968 no Brasil reiterando sua condição de país de terceiro mundo, sob uma ditadura militar, que por isso mesmo só poderia ter vivido este ano a reboque da conjuntura internacional. Nossa juventude, a seu ver, só poderia ter então vivido ecos subdesenvolvidos daquela conjuntura ímpar onde a mulher de classe média começa a trabalhar fora, há a liberação sexual pela pílula e o deboche tropicalista e uma parte da geração jovem dos anos 60 mais politizada e urbana, vivencia o radicalismo político (Veja, 06/05/1998, p.88).

Os seus ídolos são, segundo Veja, Leila Diniz e Vladimir Palmeira e aposta que, sem sombra de dúvidas, a atriz permanecerá na memória coletiva brasileira, deixando cair no esquecimento o líder estudantil, indicado candidato do PT ao governo do Rio de Janeiro 30 anos depois. Diferente de Vladimir Palmeira

Leila Diniz morrreu num acidente aéreo na Índia, em 1972, com apenas 27 anos. (...) com seu linguajar desbocado, a gravidez exposta num biquíni e uma lista infindável de amores, personalizou uma revolução nos costumes, transformou-se num dos símbolos da emancipação da mulher e deixou um sinal indelével no país (Veja, 06/05/1998, p.88).

É pela deterioração dos valores e comportamentos que contagia também o mundo subdesenvolvido que Veja repugna a implosão 
da década vitoriana dos anos de 1950 pela juventude dos anos 60 tendo seu auge em 1968 com o comércio da pílula, o divórcio, a dessacralização do matrimônio, e a extinção da relação autoritária entre pais e filhos no Brasil. Mais uma vez quem Veja traz para comentar esta mudança é o líder estudantil Vladimir Palmeira que ela tem como intuito atrelá-lo ao desmantelamento dos bons costumes (VEJA, 06/05/1998, p.88).

É bastante sintética, reducionista, a análise do movimento estudantil feita por Veja trinta anos depois:

No plano político, 68 começou com passeatas contra o regime e terminou com o país amordaçado pelo AI-5, o ato institucional que calou os políticos e a imprensa e inaugurou o terror de Estado. A tortura virou rotina e um punhado de jovens entregou-se à aventura delirante de combater o regime com a guerrilha, colhendo uma derrota definitiva. Uma boa parte dos universitários foi às ruas nas grandes cidades, um número bem menor acabou no exílio e na cadeia, e um punhado, menos de uma centena, imolou-se na insensatez da guerrilha. (...) Os jovens politizados de 1968 agiam sob o signo do voluntarismo. Democracia era um conceito vago, tanto para os generais de Brasília sob o comando do marechal Costa e Silva quanto para os jovens amantes da revolução. No fundo, o que os jovens queriam era uma coisa mais radical, uma outra ditadura - a do proletariado (VEJA, 06/05/1998, p.88).

Não há para Veja qualquer saldo positivo no ME, "autoritário e policialesco" ao contrário de grande parte da literatura acadêmica e mesmo jornalística existente e publicada trinta anos depois que evidencia o protesto estudantil como o maior opositor da ditadura militar no Brasil. Veja conclui aliviada

Em 1968, a ditadura venceu. Na eleição de 1974, o país teve a primeira chance de se manifestar com alguma liberdade e golpeou o regime duramente. Em 1984, por fim, os fantasmas de 68 foram enterrados (VEJA, 06/05/1998, p.88).

Veja já antecipava na comemoração dos 30 anos a conclamação feita por Sarcozy durante as comemorações dos 40 anos de 1968: "E, na França, berço dos protestos libertários de Maio de 1968, o presidente eleito Nicolas Sarcozy leva adiante uma 'cruzada' para 'liquidar de uma vez' com a herança daquele período".

3 http://g1.globo.com/sites/Especiais/Noticias/0,,MUL464249-15530,00.html. 
Pois, na versão de Veja, os estudantes foram responsáveis, inclusive, pelo AI-5, omitindo o fato de ela mesma ter pedido o endurecimento do regime frente à perigosa atuação do ME. $\mathrm{O}$ tiro sai pela culatra e Veja se exime de qualquer responsabilidade uma vez que, devido à censura, também passa a ser alvo do endurecimento do regime tão esperado por ela.

\section{40 anos de Veja: a juventude vitoriana revigorada}

A edição dos 40 anos de Veja é aberta com um editorial apresentando os motivos da comemoração, explicitando claramente que sua idéia de justiça social só pode ser alcançada através dos bons resultados no panorama econômico e político mundial:

Esta edição Especial de VEJA comemora os primeiros quarenta anos de história da revista com uma retrospectiva dos principais acontecimentos no Brasil e no mundo, com destaque para 1968, o ano de criação da revista, e 2008, quando os brasileiros finalmente começam a desfrutar de maturidade econômica, política e social conquistada no decorrer das quatro últimas décadas (grifo meu). É fundamental, para isso, que a revista seja independente, isenta, inteligente e responsável. (...) Que busque objetividade. E que seja comprometida - sempre - com a liberdade e a verdade (VEJA, 09/2008, p.14).

Contudo, a despeito de sua pretensa neutralidade, a revista já inicia suas comemorações dando o tom de toda a edição: a crítica à esquerda e aos movimentos anti-capitalistas, onde seus interesses passam a ser a preservação do status quo que paira no ar - sem chão social, naturalizando as relações de classe, fruto das capacidades individuais, recriando o comportamento socialmente aceito. Os "novos costumes", os novos padrões de organização familiar e de consumo propagados por Veja têm como alvo a classe média, especialmente em ascensão, e o grupo numericamente pequeno, mas economicamente mais privilegiado (SILVA, 1998). O intitulado "admirável mundo novo" de Veja por Silva é erguido em oposição ao paraíso perdido da contracultura. Notamos, assim, que Veja atinge com a mudança dos costumes dos brasileiros o auge de sua atitude como veículo de espetacularização, enaltecendo a 
uniformização da cultura moldada por uma minoria capitalista dominante que estimula o comportamento de consumo e o cultivo da postura de passividade e contrária à atitude contestatória frente à sociedade vigente.

Para Veja a maturidade política só é alcançada pela população brasileira à medida em que ela se afasta de 1968; não apenas de um regime obscuro implantado com o AI-5, mas principalmente da agitação juvenil que buscou varrer os domínios do capitalismo e corromper os valores morais. Tanto assim que em maio de 2008 seus exemplares não fazem qualquer referência aos movimentos contestatórios de 1968. Um silêncio que define uma fala. A pretensa neutralidade de Veja é, ao contrário um forte arrimo ao neoliberalismo que, no Brasil, teve na revista um precursor, agindo como seu ativo intelectual durante toda a década de 1990 uma vez que vê no advento de 1989 o "fim do comunismo" e se sente à vontade para falar, mais uma vez em mundo novo, moderno e melhor que daí emerge, vestindo a camisa do "fim da história" (cf. SILVA, 2008).

A primeira "celebridade" a ser comentada na edição de Veja de setembro de 2008 é o escritor e diretor italiano Píer Paolo Pasolini que, segundo Veja em 1968, era um "homem sem ilusões" (VEJA, 09/2008, p.98). Nas palavras de Veja

Para ele, a agitação, em que pese toda a gritaria anti-sistema, reforçou o capitalismo ao liberá-lo das amarras de valores arcaicos no terreno do comportamento - valores que o impediam de expandir-se em novas frentes mercadológicas. Ou seja, os que pretendiam derrubá-lo o ajudaram. Sem se darem conta, portanto, hippies, estudantes e outros revoltosos participaram de uma transformação do mundo, sim, mas na direção oposta à pretendida pelo ideário esquerdista - e para melhor, embora Pasolini certamente discordasse dessa conclusão (VEJA, 09/2008, p.98).

Na interpretação de Veja desvela-se seu discurso conservador, detrator dos contestadores e a sua opção pelo desenvolvimento da sociedade capitalista expressa em duas das teses desenvolvidas por Hirschman para a análise dos mais de duzentos anos da retórica conservadora, ou seja, a tese da inutilidade que afirma que todas as tentativas de transformações sociais são nulas, e a tese da per- 
versidade que parte do pressuposto de que toda ação deliberada para romper com a ordem política, social e econômica é abortiva, pois, na tentativa de impor à sociedade uma direção determinada, consegue fazê-la movimentar, só que na direção oposta à almejada, servindo apenas para exacerbar os fatores que ela deseja solucionar (HIRSCHMAN, 1995, p.73).

Em seguida, Veja continua a desconsiderar totalmente o fato de 1968 ter sua forte existência e especificidade no Brasil, ao afirmar que no "Brasil, a nostalgia de 1968 só pode ser importada" (Veja, 09/2008, p.98) reforçando mais uma vez a tese de que em país de terceiro mundo o que houve foi no máximo ecos de 1968, o que facilitaria a negação de seu passado tão almejada pela revista.

A revista Veja como instrumento de dominação tem tido uma atuação política que influencia a construção simbólica/ideológica da história brasileira e embora sempre queira aparecer como neutra, está o tempo todo buscando formular políticas, programas e projetos para o Brasil bastante demarcados politicamente e comprometidos com a modernização capitalista, desconsiderando, para tanto, o seu passado. "Não, não é preciso ter saudades do Brasil de 1968, como se verá nas próximas páginas" (VEJA, 09/2008, p.99).

Um dos episódios selecionados por Veja em seu aniversário é a passeata dos Cem Mil em 26 de junho de 1968 no centro do Rio. Veja ao reconstruir este acontecimento, atribuindo-o apenas ao repúdio do assassinato de Edson Luís pela PM em 28/03/1968 procura dar um tom de certo atraso do protesto estudantil, uma vez que ela omite os episódios importantes que envolvem os estudantes e sucedem a passeata, dentre os quais podemos citar a "Sexta-feira sangrenta" em 21/06/1968, onde 18 populares e um PM são mortos durante uma manifestação estudantil no centro do Rio. Este sim é o fato que antecede a "grande passeata" e, aliado à brutalidade do assassinato de Edson Luís, leva 100 mil pessoas às ruas no Rio de Janeiro. O intuito de Veja é claro: minimizar as causas que levam o ME à ação e também, talvez, reduzir a brutalidade da ditadura desvinculando-a das atrocidades policiais. Veja tira todo o mérito do ME de organizar a passeata e de serem os estudantes as vítimas das atrocidades da ditadura porque a opção deles era pela ditadura do proletariado e não pela democracia. 
Apenas a população e Veja nutriam este propósito: a luta pela "verdadeira" democracia. Veja continua o seu relato atrelando o seu surgimento a este sentimento de esperança e distanciando- o da agitação totalitária e comunista estudantil. Veja ao afirmar que o ME acreditava que seria possível derrubar "os militares no grito", denigre explicitamente a sua imagem e a dos políticos de oposição que qualifica de "um tanto perdidos", mesmo dizendo que está contrária à ditadura, dando assim uma no cravo e uma na ferradura, pois, com seu relato dos acontecimentos do ano de 1968 apoiará os atos do regime que servirem para punir o esquerdismo. Tanto assim que culpabiliza os estudantes e a esquerda pela reação dos militares que desembocará no AI-5.

Veja, sem qualquer contextualização, transcreve duas citações suas datadas de 1968 sobre a morte de Edson Luís e a Passeata dos Cem Mil. Mas ao consultarmos seus exemplares de 1968, buscamos interpretar o posicionamento de Veja no calor da hora dos acontecimentos, com o intuito de entender quais as escolhas de Veja daquilo que foi importante para a sua consolidação durante esses 40 anos de história, e quais as suas principais características discursivas na sua efetivação e ainda que memória constrói para si mesma e para seu público leitor. Veja ao noticiar o episódio da morte de Edson Luís, caracterizando-o como um conflito entre os estudantes e a polícia, está, em linhas gerais, centrada na discussão dos "culpados" pela utilização da violência, apontando para a utilização da violência pelos estudantes, a partir de então, mas ao mesmo tempo afirma que esta violência ocorre neste momento também como resposta da violência policial (cf. Valle, 2008), fato que Veja omite totalmente 40 anos depois, enfatizando apenas o radicalismo estudantil.

Ao tratar do movimento estudantil nesta edição especial, Veja continua a desconsiderá-lo totalmente enquanto uma força política organizada na contra-corrente da literatura existente sobre a época onde se enfatiza a importância do ME enquanto ator fundamental no combate à ditadura militar brasileira ${ }^{4}$. Nas suas palavras:

\footnotetext{
${ }^{4}$ Nas palavras de Araujo a importância de 1968: "1968 tornou-se uma data emblemática e simbólica no campo da cultura e da política, não apenas para a geração que participou dos eventos daquele ano, mas também para toda a mídia impressa, virtual e eletrônica, assim como para a comunidade acadêmica e universitária" (2009, p.17).
} 
Em 1968, a oposição à ditadura militar estava desarticulada. Boa parte dos líderes políticos não-alinhados aos generais havia sido cassada ou exilada e a oposição consentida como partido, o Movimento democrático Brasileiro (MDB), ainda engatinhava. Nesse vácuo, o movimento estudantil transformou-se na válvula de escape pela qual a sociedade conseguia manifestar seu descontentamento com as arbitrariedades dos militares. Muitos dos universitários que protestavam contra os generais eram movidos pela legítima aspiração de lutar pela volta à democracia ao país. Mas também não era pequeno o número daqueles que queriam apenas trocar um regime de exceção por outro, e defendiam a instalação de um regime comunista no Brasil. Nos campus foram criadas praticamente todas as organizações marxistas que escolheram o caminho do terrorismo (Veja, 09/2008, p.102, grifo meu).

Aqui, Veja atrela o ME anacronicamente ao terrorismo, criminalizando seus membros, uma vez que ele ainda estava atuante enquanto movimento de massas. E continua:

Além do esquerdismo, outro problema dos estudantes em 1968 era que eles deixavam se guiar por líderes como Vladimir Palmeira, Luís Travassos e José Dirceu, envolvidos em projetos personalistas. Para essa turma, o essencial era consolidar e ampliar a própria influência. No segundo semestre de 1968, Dirceu e Travassos disputavam cada centímetro de poder dentro da União Nacional dos Estudantes (chamada por Veja de "ex-UNE, por estar relegada à clandestinidade) (Veja, 09/2008, p.102).

Veja está desconsiderando propositadamente as diferentes tendências do ME e sua alta representatividade em 1968, um dos anos em que a UNE talvez tenha atingido o seu maior poder de representatividade e ação política e utiliza-se da mesma arma policialesca da ditadura de caça às bruxas ao tentar criminalizar as suas lideranças. "Os dois arrastaram os estudantes para um malfadado congresso na cidade de Ibiúna, em São Paulo" (Veja, 09/2008, p.102). Como se não bastasse, a revista trata os estudantes organizados em suas entidades representativas como massa de manobra:

Objetivo era decidir quem seria o novo presidente da entidade. Sem nenhum esforço, a polícia descobriu o local do encontro e prendeu 712 participantes. Morria ali o movimento estudantil. $\mathrm{O}$ de hoje não passa de uma paródia financiada com recursos liberados pelo governo (Veja, 09/2008, p.102-103). 
Deste último relato de Veja, podemos depreender a sua não fidedignidade aos fatos uma vez que 40 anos antes ela enfatizou, como vimos, que as manifestações estudantis eclodiram em vários estados a despeito da prisão de suas lideranças e em protesto contra elas e, agora, ela afirma que o ME termina com o Congresso de Ibiúna em 1968. O seu relato no calor da hora, ao contrário desse, invalida ao mesmo tempo essa sua nova forma de recuperar a história dos estudantes onde eles seriam, de fato, massa de manobra se o ME estivesse terminado no 30ํㅡㄹ Congresso de Ibiúna.

Mas, sem dúvida, a caça às bruxas aos líderes foi uma das principais marcas que Veja em seu discurso durante os 40 anos quis preservar e manter vivo para a memória coletiva e que já estava presente desde os seus primeiros exemplares. Novamente Veja descontextualiza passagens sobre o ME visando apenas a denegrir e enfatizar o seu caráter fragmentado e esquerdista. Em contrapartida, enaltece os valores morais calcados na justiça social que leva a manutenção do status quo imprescindíveis à juventude se ela quiser atingir um mundo melhor. Emerge, assim a possibilidade da juventude vitoriana revigorada.

Veja contribuiu, assim, para o fechamento da possibilidade de fazer a crítica à sociedade regida pelos valores da mercadoria, determinando as necessidades individuais e coletivas e combatendo qualquer tipo de oposição ao sistema político e econômico do mercado. Pois na sociedade do espetáculo as pessoas se comportam de acordo com os modos apresentados pela mídia, levando ao desejo de consumo inscrito na uniformização exercida pela cultura de massa. Para tanto Veja buscou durante seus 40 anos refutar a contestação dos valores sociais que ocorreu mundialmente em 1968 pondo em risco os padrões de comportamento, pensamento e consumo. Por isso Veja traz como preocupação central de suas matérias sobre este ano ímpar, o terreno do comportamento juvenil à luz do entretenimento. Veja ao fazer alusão à juventude dos anos 60 se utiliza do subtítulo "A Escola de Dirceu" seguido do texto:

José Dirceu é um homem de múltiplos talentos. Já foi deputado federal, presidente do PT, ministro da Casa Civil e chefe dos mensaleiros. Hoje é um consultor empresarial quentíssimo, embora não diga quais clientes costuma atender. Sua "vida profissional" - por assim dizer - começou no movimento 
estudantil. Ele foi um dos personagens mais citados por Veja em 1968. Seu grande feito foi liderar os esquerdistas na estúpida batalha da Rua Maria Antônia, em São Paulo, que opôs estudantes do Mackenzie aos da Filosofia da USP e terminou com um rapaz morto. O líder, é claro, não sofreu nenhum arranhão. Depois, acabaria preso no Congresso da UNE em Ibiúna. Ele e outros líderes estudantis ficaram detidos por um mês em uma prisão no litoral paulista. Lá, os prisioneiros dividiram-se em três turmas. Enquanto uma cuidava da roupa e a outra da limpeza, a terceira descansava. 'Dirceu foi unanimemente apontado pelos colegas como o mais preguiçoso', registrou VEJA. Mesmo em cana, fugia do trabalho. Liberado em troca do embaixador americano Charles Burke Elbrick, seqüestrado em 1969, partiu para o exílio em Cuba, onde fez uma plástica para mudar de rosto. Voltou ao Brasil escondido, em 1975, e casou-se com uma mulher a quem não revelou a verdadeira identidade. Com a abertura política, abandonou a moça, desfez a plástica e voltou a agitar, agora no PT. Chegou ao seu ápice como ministro -chefe da Casa Civil, quando, segundo o Ministério Público, se tornou chefe da "sofisticada organização criminosa” que criou o mensalão e pretendia eternizar-se no poder. O menino é mesmo pai do homem. (Veja, 09/2008, p.103)

De seu relato durante 1968, no mesmo encarte, Veja recorta a seguinte descrição:

O presidente da ex-UEE, José Dirceu, dorme cada noite numa casa diferente, passa o dia todo entre seus colegas, na Faculdade de Filosofia de São Paulo, e quando sai está sempre armado e protegido por dois guarda-costas. (...) Seu nome é o primeiro da lista de estudantes que o Dops quer prender (Veja, 09/2008,p.103).

Destas duas citações podemos, sem sombra de dúvidas, extrair as principais características de uma juventude que está implícita em uma de suas principais lideranças, condenada com veemência por Veja: ser tutelada por uma liderança "profissional" de esquerda, subversiva, agitadora, de falsa identidade, preguiçosa, personalista, inconsequente, matriculada na escola do crime. Dessa forma Veja quer enterrar 1968 e com ele a participação política contestadora da juventude que deve almejar apenas um mundo melhor sinônimo de roupas de marca, passeios nos shopping e ligados nos seus aparelhos eletrônicos, em total consonância com a indústria cultural, ou seja, com uma unanimidade de aspirações e o desinteresse em expressar rebeldia ou deflagrar movimentos de protesto. (Veja, "O planeta teen”, 19 de abril de 1995, p.108)

Intercom - RBCC 


\section{Considerações finais}

Para Veja, como vimos, em 2008 os "brasileiros finalmente começam a desfrutar de maturidade econômica, política e social conquistada no decorrer das quatro últimas décadas (grifo meu)". E, sem sombra de dúvidas, ela cumpriu seu papel para que o Brasil possa estar usufruindo dos "bons resultados no panorama econômico e político mundial", particularmente com o seu empenho na escola da juventude onde devem ser transmitidos conteúdos neoliberais e os da indústria cultural com a metodologia da sociedade do espetáculo. Para tanto acompanhamos o seu relato durante quatro décadas sobre o ME em 1968 no Brasil, então, na periferia do mundo, onde através de um discurso que busca distanciar cada vez mais da fidedignidade dos fatos, procura elaborar uma construção de um único modo possível de vida desde que rechaçada a subversão. Ao exercer cada vez mais um Jornalismo espetacular, torna a imagem de 1968 cada vez mais debochada.

A imagem construída pela revista Veja do movimento estudantil e de todas as suas opções políticas, culturais, comportamentais, constituem as várias facetas do inimigo externo que passa a agir internamente e precisa ser extirpado para que a justiça social, a verdade, ou seja, a juventude de Veja possa viver plenamente sua era vitoriana. Assim, com a ausência de movimentos contestatórios, abre-se o espaço para que a mídia homogeneíze os comportamentos, corpos e mentes.

\section{Referências}

ADORNO, Theodor. Indústria cultural e sociedade. São Paulo: Paz e Terra, 2009.

FICO, Carlos \& ARAUJO, Maria Paula (orgs.). 1968: 40 anos depois - história e memória. Rio de Janeiro: 7Letras, 2009.

CARNEVALLI, Maria Alice. Indispensável é o leitor: o novo papel das revistas semanais de informação no Brasil. Tese de Doutoramento. ECA/USP, São Paulo, 2003.

COELHO, Cláudio Novaes Pinto \& VALLE, Maria Ribeiro do. "A Revista 
Veja e o Movimento Estudantil em 1968: entre o engajamento e o entretenimento". Clio - Série Revista de Pesquisa Histórica. Recife, v. 26, n.1, p.138-154, 2008.

DEBORD, Guy. A sociedade do espetáculo. Rio de Janeiro: Contraponto, 1997.

DORNELES, Vanderlei. De verbal para o visual: status da imagem nas revistas semanais de informação. Trabalho apresentado ao NP - Jornalismo, do IV Encontro dos Núcleos de Pesquisa da Intercom. CONGRESSO BRASILEIRO DE CIÊNCIAS DA COMUNICAÇÃO. (s/d). Disponível em: http://www.portcom.intercom.org.br/pdfs/32712922029158351012458603287774297742.pdf. Acesso em: 07 dez. 2012.

HIRSCHMAN, A. O. A retórica da intransigência: perversidade, futilidade, ameaça. São Paulo, Companhia das Letras, 1995.

MARCUSE, H. A ideologia da sociedade industrial - $\mathrm{O}$ homem unidimensional. Rio de Janeiro, Zahar, 1982.

PORTO, Marcos M. Caetano; CAIXETA, Geovane F. A publicidade impressa como veículo de espetacularização. Pesquisere - Revista do Núcleo Interdisciplinar de Pesquisas e Extensão do UNIPAM. Patos de Minas, UNIPAM, n.6, p.198-212, outubro 2009.

SILVA, Carla L. Souza da. O "admirável Mundo" de Veja: Influências Sociais de uma revista de informação”. História Actual Online, n. 15, p. 89-105, Invierno 2008.

SODRÉ, Muniz. Comunicação do grotesco. Petrópolis: Vozes, 1988.

VALLE, Maria Ribeiro do. 1968: o diálogo é a violência. 2.ed. Campinas: Editora da Unicamp, 2008. 


\section{Quem tem medo da Pesquisa Empírica}

Nesta coletânea estão reunidos alguns dos trabalhos apresentados no XXXIV Ciclo de Estudos Interdisciplinares da Comunicação, evento que discutiu o tema central do congresso de 2011, o mesmo que dá nome a este livro. Eles estão agrupados em quatro partes: A pesquisa empírica e o campo acadêmico da Comunicação; Conhecimento empírico crítico: extensões de McLuhan na Comunicação; A pesquisa empírica como instrumento de Comunicação Científica; e A pesquisa empírica aplicada: métodos, desafios institucionais, meios de comunicação, educação e interfaces.

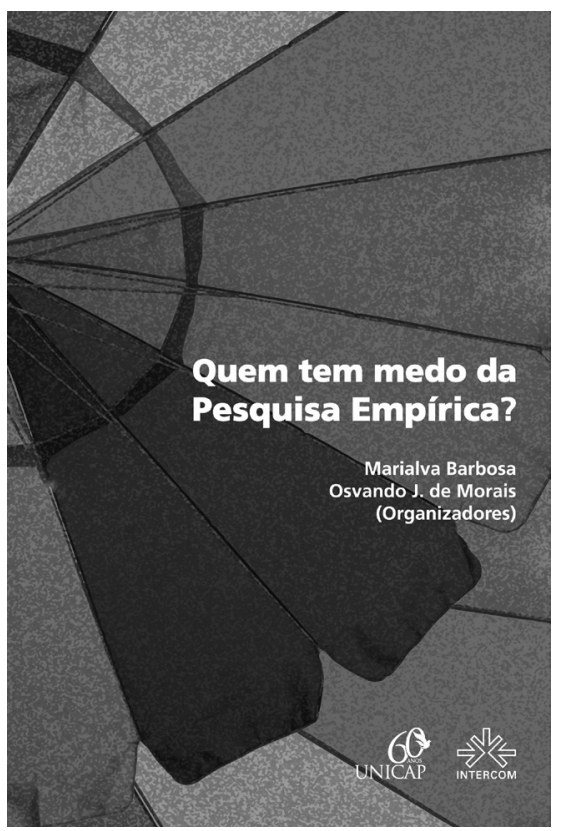

FAÇA SEU PEDIDO

pelo telefone (0xx11) 2574-8477,

e-mail: intercom@usp.br

ou acesse a Livraria Virtual da Intercom:

http://www.intercom.org.br 